International Journal of Agriculture, Environment and Bioresearch

Vol. 06, No. 04; 2021

ISSN: $2456-8643$

\title{
EFFECT OF ETHANOL AND AQUEOUS EXTRACT OF SALVIA ROSMARINUS ON BACTERIA ISOLATED FROM BURNS INFECTION
}

\author{
Anmar Saadi Aboud \\ Mustansiryah University, College of Sciences, Department of Biology. Baghdad, Iraq \\ https://doi.org/10.35410/IJAEB.2021.5659
}

\begin{abstract}
The aqueous and ethanol extracts of Salvia rosmarinus used for the treatment of infections disease were tested for their active against gram positive and gram negative bacteria isolated from burns infection culture using the broth dilution and disc diffusion method. Results of this study revealed the presence of phytochemical which were active against gram positive and negative bacteria. Ethanol extracts of plant showed highest activity other than aqueous extract. The minimum inhibitory concentration (MIC) of the aqueous extracts on the test organism was 25- $100 \mathrm{mg} \backslash \mathrm{ml}$, while that of the ethanol extract ranged between $25-50 \mathrm{mg} \backslash \mathrm{ml}$ on the test organisms, the minimum bacterial concentration (MBC) ranging between 25-100 mg $/ \mathrm{ml}$ for ethanol extract, and 25-200 mg $\backslash \mathrm{ml}$ for aqueous extracts. The highest activity at $45 \mathrm{oC}$ was demonstrated by the ethanol extracts of S. rosmarinus against Staphylococcus aureus and Klebsiella spp. . In this study plant extracts against gram negative bacteria showed activity in acidic $\mathrm{pH}$ only in contrast of gram positive bacteria which were constant in plant extract. S. rosmarinus contained essential elements at higher levels. The results of this study suggest the possibility of using the ethanolic extracts of plant in treating diseases caused by the test organisms, especially when prepared at acidic $\mathrm{pH}$.
\end{abstract}

Keywords: Plant extract, Salvia rosmarinus, Antimicrobial activity, Bacteria.

\section{INTRODUCTION}

Plants play a vital role in maintaining human health and contribute towards improvement of human life. They are important components of medicines, cosmetics, dyes, beverages etc. [1] Although hundreds of plant species have been tested for antimicrobial Properties [2].

There are many cases of infection by drug resistant bacteria whereas few drugs are available effective for the treatment of such patients. Thus, it is urgently necessary to discover or develop new drugs that are effective on such drug resistant bacteria. We have been trying to discover novel compounds, such as antimicrobial compounds and inhibitors of drug resistance systems in bacteria, [3] that are effective against multidrug-resistant bacteria. Though Salvia rosmarinus L.is known as one of the herbs that has antimicrobial activity, there are few papers that have showed its antibacterial activity, as well as has shown anti-fungal, anti-viral properties that make it a useful weapon in combating many illnesses [4]. S. rosmarinus is cultivated in several countries mainly to obtain dried leaves to be used as raw material in medicine, perfumery and food industry [5]. Oleander comprises one of the largest genera of flowering plants in the 
Vol. 06, No. 04; 2021

ISSN: $2456-8643$

world [6]. A large number of preservative compounds have been introduced on to the market but many of them have not gained acceptance because of chemical toxicity, Lowe efficacy, high cost, or corrosiveness [7]. Certain wood preservatives have been banned or limited for some applications such as chromated copper arsenate in some European countries, the United States, and Japan [8] Since some natural extractives contain tannin or have toxic effects against biotic agents, they could be preferred for protection of wood or wood based objects against destroying organisms [9].

Ability of natural plant extracts to protect wood against degrading fungi and insects have been one possible approach for Oleander is one of the most poisonous plants and contains numerous toxic compounds. Many of Oleander's relatives have similar leaves and contain toxic compounds. The entire plant including the milky white sap is toxic and any part can cause an adverse reaction. Oleander is also known to hold its toxicity even after drying [10]. The objective developing new wood preservatives [11and 8]. The goal of this investigation was to discover plant products that inhibit micro-organisms, especially that cases burns infection.

\section{MATERIALS AND METHODS}

\section{Collection of plant samples}

The medicinal plants used for the experiment was identified according to various literatures, and including other pertinent taxonomic literature .The part of the plant used is the leaves. Collected plants were washed thoroughly and chopped into small pieces shade dried and grinded into powdered form. Clean and dry separating funnel was taken.

\section{Test microorganisms}

Bacterial species Shigella dysenteriae; Aeromonas hydrophila ; Escherichia coli ; Enterobacter spp ; Klebsiella spp ; Pseudomonas aeruginosa and Staphylococcus aureus were all obtained from the microbiology laboratory in Mustansiryah University.

\section{Culture medium and inoculum}

The stock cultures of microorganisms used in this study were maintained on Plate Count Agar slants at $+4^{\circ} \mathrm{C}$. Cell suspensions were prepared by inoculation of each bacterium into $10 \mathrm{ml}$ of Nutrient broth. Incubation was performed at $37^{\circ} \mathrm{C}$ for $24 \mathrm{~h}$. On the next day Mueller-Hinton Agar (MHA) was prepared and cooled to $45^{\circ} \mathrm{C}$. Bacterial suspension was added into MHA to give a final concentration of $10^{7}$ bacteria/ml and plated out.

\section{Phytochemical screening}

The plant extracts was screened for phytochemical constituents using standard procedures of analysis [12 and 13].

\section{Antibacterial activity}

The plate-hole diffusion assay as described by [14] was used to determine the growth inhibition of bacteria by the plant extract. The isolated bacteria from wound infection were obtained. The tests were carried out by using a stock concentration of $500 \mathrm{mg} / \mathrm{ml}$ prepared by dissolving $1 \mathrm{~g}$ of the ethanol extract and aquatic extract into $2 \mathrm{ml}$ of distilled water. Nutrient agar was prepared and $25 \mathrm{ml}$ each was poured into sterile petri dish. This was allowed to solidify and 
dry. Using a sterile cock-borer of $9 \mathrm{~mm}$ diameter three equi-distant holes per plate were made in the set agar and were inoculated with $0.5 \mathrm{ml}$ over night suspension of the bacteria. Thereafter, the wells (holes) were filled with the extract solution volume $100 \mu \mathrm{l}$ at varying concentrations of $500 \mathrm{mg} / \mathrm{ml}, 400 \mathrm{mg} / \mathrm{ml}$ and $300 \mathrm{mg} / \mathrm{ml}$ respectively. This was done in triplicate and the plates were incubated at $37^{\circ} \mathrm{C}$ for 18 hours. The antibacterial activities were observed and measured using a transparent meter rule and recorded if the zone of inhibition was $610 \mathrm{~mm}$ [15].

\section{Minimum Inhibitory Concentration (MIC)}

MIC is defined as the lowest concentration where no visible turbidity is observed in the test tube (bacteriostatic concentration). The Reuben et al.,[16] was employed. In this method, the broth dilution technique was utilized where the plant extract was prepared to the highest concentration of $500 \mathrm{mg} / \mathrm{ml}$ (stock concentration) in sterile distilled water and serially diluted (two-fold) to a working concentration ranging from $0.780 \mathrm{mg} / \mathrm{ml}$ to $200 \mathrm{mg} / \mathrm{ml}$ using nutrient broth and later inoculated with $0.2 \mathrm{ml}$ suspension of the test organisms. After 18 hours of incubation at $37^{\circ} \mathrm{C}$, the test tubes were observed for turbidity. The least concentration where no turbidity was observed was determined and noted as the minimum inhibitory concentration (MIC) value.

\section{Minimum Bacterial Concentration (MBC)}

The MBC is defined as the lowest concentration where no bacterial growth is observed (bactericidal concentration). This was determined from the broth dilution resulting from the MIC tubes by sub culturing to antimicrobial free agar as described by Usman et al. [17].In this technique, the contents of the test tubes resulting from MIC was streaked using a sterile wire loop on agar plate free of bacteria and incubated at $37^{\circ} \mathrm{C}$ for 18 hours. The lowest concentration of the extract which showed no bacterial growth was noted and recorded as the MBC.

\section{The effect of heat and $\mathrm{pH}$ on medicinal plant extract}

The samples of plant extract (one vial of $100 \mathrm{ml}$ ) were provided to determine the effect of heat on it, test samples were heated $45^{\circ} \mathrm{C}, 70{ }^{\circ} \mathrm{C}, 100{ }^{\circ} \mathrm{C}$ and $121{ }^{\circ} \mathrm{C}$ for $15 \mathrm{~min}$. [18]. To determine the effect of $\mathrm{pH}$, extracts were treated at $\mathrm{pH}$ ranges of 3 to 8 using $1 \mathrm{~N} \mathrm{HCl}$ and $1 \mathrm{~N}$ $\mathrm{NaOH}$ solutions respectively in series of test tubes for $1 \mathrm{~h}$ and then tested for antibacterial activity [19].

\section{Determination of essential elements}

Three gram of dried plant were taken and mixed with $8 \mathrm{ml}$ of concentrated $\mathrm{H}_{2} \mathrm{SO}_{4}(98 \%)$ and $2 \mathrm{ml}$ of $\mathrm{HClO}_{3}(60 \%)$ in conical flask for 24 hours which covered by watch class. Then left this mixture for 6 hours at the sand bath at $80 \mathrm{C}^{\circ}$, until the digestion material converted to white powder. Then add $8 \mathrm{ml}$ of deionized water to this powder and the trace elements were determined by flame atomic absorption spectrophotometer [20].

\section{RESULT AND DISCUSSION}

The result of the Phytochemical screening for S. rosmarinus showed the same results are presented in Table 1. This reveals moderate concentration of alkaloids, coumarines , cardiacglycosides, ratenges, phenols, flavonoids, saponins, tannins, essensial oil and terpenes some of which chemical compounds have been associated to antibacterial activities and thus have curative properties against pathogens [21] except steroids no of plant extracts contain it. Phytochemical constituents such as tannins, flavonoids, alkaloids and several other aromatic compounds are secondary metabolites of plant that serve as defense mechanisms against 
predation by many microorganisms [22]. This may therefore explain the demonstration of antimicrobial activity of $S$. rosmarinus.

Table 1: Phytochemical screening of Ethanol, Hot water and Cold water extract of S. rosmarinus

\begin{tabular}{|c|c|c|c|c|}
\hline Number & Constituents & $\begin{array}{l}\text { Ethanol } \\
\text { extract }\end{array}$ & $\begin{array}{l}\text { Hot } \\
\text { water } \\
\text { extract }\end{array}$ & $\begin{array}{l}\text { Cold water } \\
\text { extract }\end{array}$ \\
\hline \multirow[t]{2}{*}{$\mathbf{1}$} & Alkaloids & & & \\
\hline & $\begin{array}{l}\text { i.Dragendorff's } \\
\text { test ii.Meyer's } \\
\text { test }\end{array}$ & + & + & + \\
\hline \multirow[t]{2}{*}{2} & Phenols & & & \\
\hline & & + & + & + \\
\hline \multirow[t]{2}{*}{3} & Cardiac glycosides & & & \\
\hline & Killer-killanis test & + & + & + \\
\hline \multirow[t]{2}{*}{4} & Flavonoids & & & \\
\hline & $\begin{array}{l}\text { i.Shinoda's } \\
\text { test ii. } \mathrm{FeCl}_{3} \\
\text { test }\end{array}$ & + & + & + \\
\hline \multirow[t]{2}{*}{5} & Saponins & & & \\
\hline & Frothing test & + & + & + \\
\hline \multirow[t]{2}{*}{6} & Terpenes & & & \\
\hline & Salkowski test & + & + & + \\
\hline \multirow[t]{2}{*}{7} & Steroids & & & \\
\hline & $\begin{array}{l}\text { Libarman-Burchard's } \\
\text { test }\end{array}$ & - & - & - \\
\hline \multirow[t]{2}{*}{8} & Tanins & & & \\
\hline & $\begin{array}{l}\text { i. } \mathrm{FeCl}_{3} \text { test } \\
\text { ii.Lead acetate } \\
\text { test }\end{array}$ & + & + & + \\
\hline \multirow[t]{2}{*}{9} & Ratenges & & & \\
\hline & & + & + & + \\
\hline \multirow[t]{2}{*}{10} & Coumarines & & & \\
\hline & & + & + & + \\
\hline 11 & Essensial oil & & & \\
\hline
\end{tabular}


Vol. 06, No. 04; 2021

ISSN: $2456-8643$

\begin{tabular}{|l|l|l|l|l|}
\hline & + & + & + \\
\hline
\end{tabular}

Regression analysis of the relationship between size of inhibition zone ( $\mathrm{mm}$ ) and plant crude extract concentration (Log value) showed that there was a significant correlation between concentrations of tested plant extracts and the mean inhibition zone of pathogenic isolates. The in vitro antibacterial activities are shown in Table 2 . As is shown, a wide spectrum activity against some of bacterial strains studied. Amongst the Gram-positive and Gram-negative bacteria, Gram positive bacteria $\mathrm{S}$. aureus were inhibited by plant extract. Indifference ethanol extract of $\mathrm{S}$. rosmarinus was more effective compare two aqueous extract for the same plant ,.All Gram negative bacteria i.e. E. spp ,S. dysenteriae, A . hydrophila were found to be resistant to all of the extracts of S. rosmarinus, Exceptionally K .spp, E . coli and P. aeruginosa showed zone of inhibition. Were as all gram negative bacteria i.e. S. Dysenteriae, A . hydrophila, K . spp , E . coli and $\mathrm{P}$. aeruginosa gave antibacterial activity as zone of inhibition around the extract of S. rosmarinus, but only E . spp was resistant to all of the extract preparation. The demonstration of antibacterial activity against both gram positive and gram negative bacteria may be indicative of the presence of broad spectrum antibiotic compounds [23].Several workers have reported that many plants possess antimicrobial properties including the parts which include; flower, bark, stem, leaf, etc. It has been shown that when solvents like ethanol, hexane and methanol are used to extract plant, most of them are able to exhibit inhibitory effect on both gram positive and gram negative bacteria [24].

Out of the two solvents used for extraction, the ethanol extracts showed the highest activity against the test organisms, followed by the aqueous extracts (hot \& cold). Different solvents have been reported to have the capacity to extract different phytoconstituents depending on their solubility or polarity in the solvent [22]. Ethanol extracts in this study might have had higher solubility for more phytoconstituents, consequently the highest antibacterial activity. The demonstration of antimicrobial activity by water extracts provides the scientific basis for the use of these plants in the traditional treatment of diseases, since most traditional medicine men use water as their solvent in which the decoctions are prepared.

Table 2: Antibacterial Activity of Plant Extracts against Test Organisms

\begin{tabular}{|c|c|c|c|c|c|c|c|c|}
\hline \multirow{2}{*}{$\begin{array}{l}\text { Extract/concentration } \\
\mathrm{Mg} / \mathrm{ml}\end{array}$} & \multicolumn{8}{|c|}{ Zone of inhibition (mm) } \\
\hline & Co. & P.a. & E.spp & K.spp & A.h. & S.d. & E.c. & S.a. \\
\hline Ethanol Extract of S. rosmarinus & $\begin{array}{l}500 \\
400 \\
300\end{array}$ & $\begin{array}{l}23 \\
20 \\
18\end{array}$ & $\begin{array}{l}- \\
- \\
-\end{array}$ & $\begin{array}{l}9 \\
8 \\
8\end{array}$ & $\begin{array}{l}- \\
- \\
-\end{array}$ & $\begin{array}{l}- \\
- \\
-\end{array}$ & $\begin{array}{l}28 \\
23 \\
20\end{array}$ & $\begin{array}{l}28 \\
22 \\
18\end{array}$ \\
\hline $\begin{array}{l}\text { Hot aqueous Extract of } S . \\
\text { rosmarinus }\end{array}$ & $\begin{array}{l}500 \\
400 \\
300\end{array}$ & $\begin{array}{l}18 \\
18 \\
16\end{array}$ & $\begin{array}{l}- \\
- \\
-\end{array}$ & $\begin{array}{l}7 \\
- \\
-\end{array}$ & - & $\begin{array}{l}- \\
-\end{array}$ & $\begin{array}{l}26 \\
23 \\
19\end{array}$ & $\begin{array}{l}10 \\
9 \\
7\end{array}$ \\
\hline
\end{tabular}


International Journal of Agriculture, Environment and Bioresearch

Vol. 06, No. 04; 2021

ISSN: $2456-8643$

\begin{tabular}{|l|l|l|l|l|l|l|l|l|}
\hline $\begin{array}{l}\text { Cold aqueous Extract of S. } \\
\text { rosmarinus }\end{array}$ & $\begin{array}{l}500 \\
400\end{array}$ & 18 & - & 8 & - & - & 18 & 18 \\
& 300 & 15 & - & 7 & - & - & 13 & 13 \\
\hline Control(water) & - & - & - & - & - & - & - & - \\
\hline Control(Ethanol) & - & - & - & - & - & - & - & - \\
\hline
\end{tabular}

The minimum inhibitory concentration MIC and minimum bactericidal concentration MBC results are shown in Tables 3, 4,. These tables reveal that the ranges of activity for both MIC and $\mathrm{MBC}$ are 0.780 to $200 \mathrm{mg} / \mathrm{ml}$. The highest MIC and MBC values is an indication that either the plant extracts are less effective on some bacteria or that the organism has the potential of developing antibiotic resistance, while the low MIC and MBC values for other bacteria is an indication of the efficacy of the plant extracts.

Table 3: Minimum Inhibitory Concentration (MIC) values for Bacterial Isolates Against $S$. rosmarinus extracts

\begin{tabular}{|c|c|c|c|c|c|c|c|c|c|c|c|c|c|c|c|c|c|c|c|c|c|c|c|c|c|c|c|}
\hline \multirow{3}{*}{$\begin{array}{l}\text { Bacter } \\
\text { ia } \\
\text { Isolate } \\
s\end{array}$} & \multicolumn{27}{|c|}{ Extract concentration (mg/ml) } \\
\hline & \multicolumn{3}{|c|}{0.780} & \multicolumn{3}{|c|}{1.560} & \multicolumn{3}{|c|}{3.125} & \multicolumn{3}{|c|}{6.25} & \multicolumn{3}{|c|}{12.5} & \multicolumn{3}{|c|}{25} & \multicolumn{3}{|c|}{50} & \multicolumn{3}{|c|}{100} & \multicolumn{3}{|c|}{200} \\
\hline & $\mathbf{E}$ & $\mathbf{H}$ & $\mathbf{C}$ & $\mathbf{E}$ & $\mathbf{H}$ & $\mathbf{C}$ & $\mathbf{E}$ & $\mathbf{H}$ & $\mathbf{C}$ & $\mathbf{E}$ & $\mathbf{H}$ & $\mathbf{C}$ & $\mathbf{E}$ & $\mathbf{H}$ & $\mathbf{C}$ & $\mathbf{E}$ & $\mathbf{H}$ & $\mathbf{C}$ & $\mathbf{E}$ & $\mathbf{H}$ & $\mathbf{C}$ & $\mathbf{E}$ & $\mathbf{H}$ & $\mathbf{C}$ & $\mathbf{E}$ & $\mathbf{H}$ & $\mathbf{C}$ \\
\hline P.a. & - & - & - & - & - & - & - & - & - & - & - & - & - & - & - & $\mathrm{I}$ & $\mathrm{I}$ & $\mathrm{I}$ & + & + & + & + & + & + & + & + & + \\
\hline E.spp & - & - & - & - & - & - & - & - & - & - & - & - & - & - & - & - & - & - & - & - & - & - & - & - & - & - & - \\
\hline K.spp & - & - & - & - & - & - & - & - & - & - & - & - & - & - & - & - & - & - & - & - & - & - & - & - & - & - & - \\
\hline A.h. & - & - & - & - & - & - & - & - & - & - & - & - & - & - & - & - & - & - & - & - & - & - & - & - & - & - & - \\
\hline S.d. & - & - & - & - & - & - & - & - & - & - & - & - & - & - & - & - & - & - & - & - & - & - & - & - & - & - & - \\
\hline E.c. & - & - & - & - & - & - & - & - & - & - & - & - & - & - & - & - & - & - & - & I & I & + & + & I & + & + & + \\
\hline S.a & - & - & - & - & - & - & - & - & - & - & - & - & - & - & - & $\mathrm{I}$ & - & - & + & - & - & + & $\mathrm{I}$ & - & + & + & - \\
\hline
\end{tabular}

S.d = S. dysentriae; S. $a=$ S. aureus; A.h.= A. hydrophila; E.c.= E. coli ; E.spp. = Enterobacter spp: K.spp = Klebsiella spp: P.a.=P. aeruginosa

- = Resistance (growth of bacteria)

$+=$ Concentrations show no turbidity (inhibition of bacterial growth)

$\mathrm{I}=$ least concentration showing no turbidity (MIC)

E=Eethanol extract

$\mathrm{H}=$ Hot aqueous extract

$\mathrm{C}=$ Cold aqueous extract 


\section{Bacterial Concentration (MBC) Values for Bacterial Isolates against $S$. rosmarinus extracts} Table 4: Minimum

\begin{tabular}{|c|c|c|c|c|c|c|c|c|c|c|c|c|c|c|c|c|c|c|c|c|c|c|c|c|c|c|c|}
\hline \multirow{4}{*}{\begin{tabular}{|l} 
Bacter \\
ia \\
Isolate \\
$\mathrm{s}$
\end{tabular}} & \multicolumn{27}{|c|}{ Extract concentration $(\mathrm{mg} / \mathrm{ml})$} \\
\hline & \multicolumn{3}{|c|}{$\mathbf{0 . 7 8 0}$} & \multicolumn{3}{|c|}{1.560} & \multicolumn{3}{|c|}{3.125} & \multicolumn{3}{|c|}{6.25} & \multicolumn{3}{|c|}{12.5} & \multicolumn{3}{|c|}{25} & \multicolumn{3}{|c|}{50} & \multicolumn{3}{|c|}{100} & \multicolumn{3}{|c|}{200} \\
\hline & $\mathbf{E}$ & $\mathbf{H}$ & C & $\mathbf{F}$ & $\mathbf{H}$ & C & $\mathbf{E}$ & $\mathbf{H}$ & $\mathbf{C}$ & $\mathbf{E}$ & $\mathbf{H}$ & $\mathrm{C}$ & $\mathbf{E}$ & $\mathbf{H}$ & $\mathbf{C}$ & $\mathbf{E}$ & $\bar{H}$ & $\mathbf{C}$ & $\mathbf{E}$ & $\mathbf{H}$ & $\mathbf{C}$ & $\mathbf{E}$ & $\mathbf{H}$ & $\mathbf{C}$ & $\mathbf{E}$ & $\mathbf{H}$ & $C$ \\
\hline & & & & & & & & & & & & & & & & & & & & & & & & & & & \\
\hline & & - & - & - & - & - & - & - & - & - & - & & - & - & - & B & B & B & + & + & + & + & + & + & + & + & $T$ \\
\hline E.sp & & - & 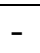 & - & - & & - & - & - & - & - & & - & - & & - & - & - & - & - & - & - & - & - & - & - & - \\
\hline K.spp & & - & - & - & 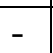 & - & - & - & - & - & - & & - & - & & - & - & - & & - & - & - & - & - & - & - & - \\
\hline$\overline{A .1}$ & & - & & - & - & & 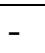 & - & - & - & & & - & & & - & - & - & - & - & - & - & - & - & - & - & 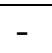 \\
\hline S.d. & & - & - & - & 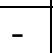 & - & - & - & - & - & - & & - & - & & - & 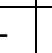 & - & - & - & - & - & - & - & - & - & - \\
\hline E.c. & & - & & - & 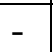 & - & - & - & - & - & - & & - & - & & & 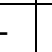 & - & - & - & - & $\mathrm{B}$ & B & - & + & + & $B$ \\
\hline S.a & - & - & - & - & - & - & - & - & - & - & 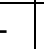 & - & - & - & - & $\mathrm{B}$ & - & - & + & - & - & + & B & - & + & + & \\
\hline
\end{tabular}

S.d = S. dysentriae; S. $a=$ S. aureus; $A . h .=$ A . hydrophila; E.c. $=$ E. coli $; \quad$ E.spp. $=$ Enterobacter spp: $K . s p p=$ Klebsiella spp: $P . a .=$ P. aeruginosa

- = Resistance (growth of bacteria)

$+=$ Concentrations show no turbidity (inhibition of bacterial growth)

$\mathrm{B}==$ Minimum Bactericidal $(\mathrm{MBC})$

$\mathrm{E}=$ Ethanol extract

$\mathrm{H}=$ Hot aqueous extract

$\mathrm{C}=$ Cold aqueous extract

Result of the effect of temperature on the plant extracts showed that various temperature ranges of $45,70,100$ and $121^{\circ} \mathrm{C}$ had various effect on the antimicrobial activity of the extracts (Fig 4,5and 6 ), in methanol extracts of S. rosmarinus the $45^{\circ} \mathrm{C}$ was the effective temperature (diameter of zone of inhibition $25 \mathrm{~mm}$ ), , while A. hydrophila had the constant activity in different used temperatures. As can clearly be seen by this figures, the rest bacteria did not response to these temperatures in ethanol, both aqueous extract (No zone of inhibition).
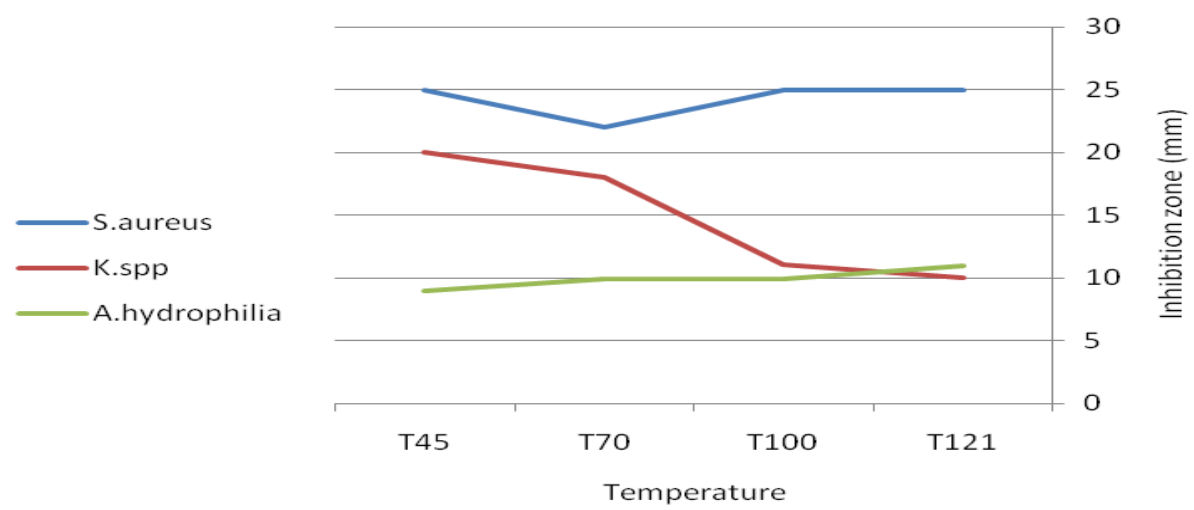

Fig 4. Effects of temperature on antimicrobial activity of ethanol extract $\mathrm{S}$. rosmarinus 


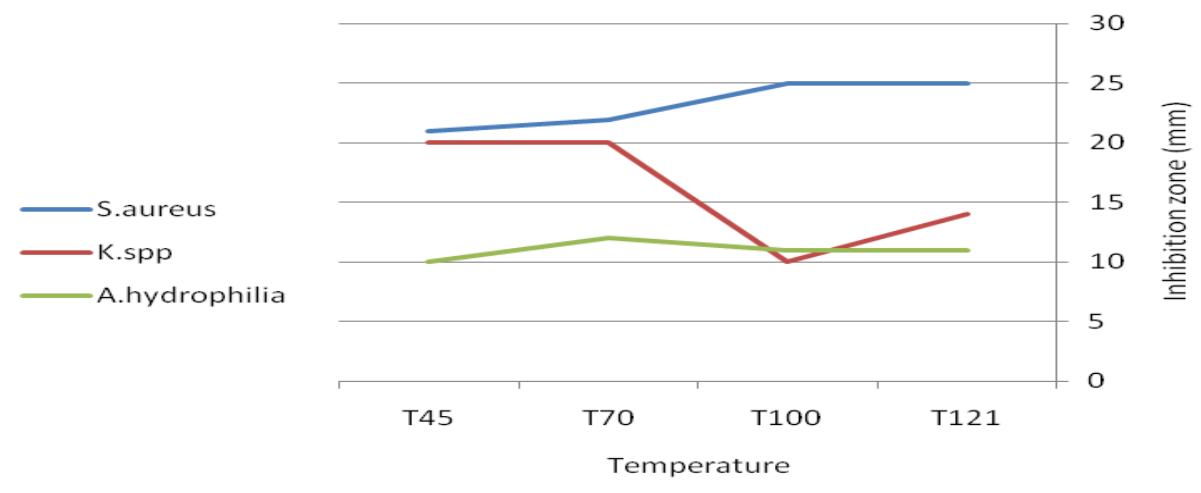

Fig 5. Effect of temperature on antimicrobial activity of Hot aqueous extract $\mathrm{S}$. rosmarinus

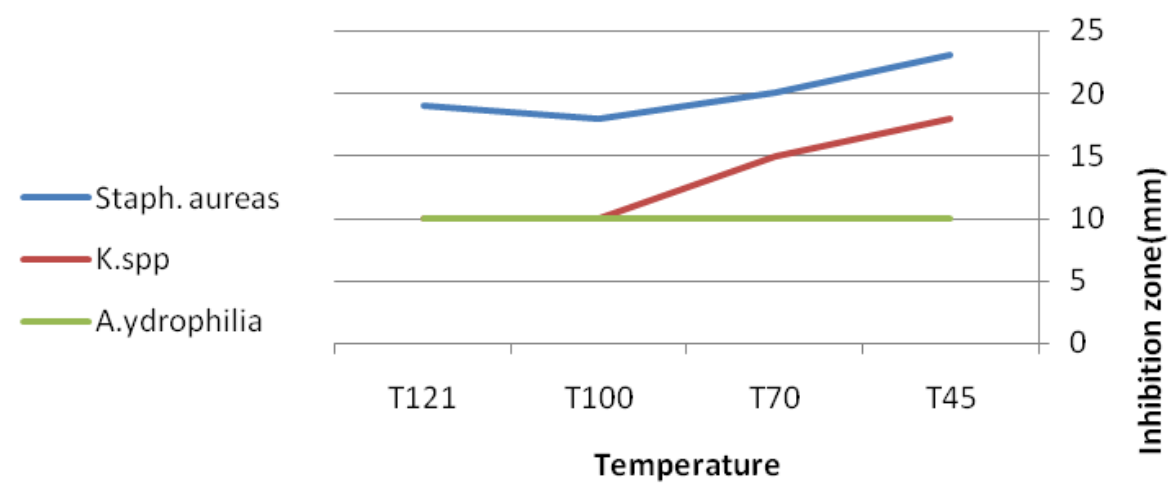

Fig 6. Effect of temperature on antimicrobial activity of Cold aqueous extract S. rosmarinus

The activity slightly increased at acidic $\mathrm{pH}$ (3 to 5). While at alkaline $\mathrm{pH}$ the activity of the plant extracts reduced except for A. hydrophila in plant extracts (Fig 10,11and 12). The antibacterial activity of the extracts slightly increased at acidic $\mathrm{pH}$. Increase in activity of phyotoconstituents in the presence of acidic medium has earlier been reported [25]. The local application of these plants involves the addition of high doses of potash which is a strong basic salt, and for the fact that the activity of the extracts reduced at alkaline $\mathrm{pH}$ in this study, it may explain why the plant concoction is taken for longer period of time before any curative effect is noticed. In this study noticed that gram positive bacteria S. aureus gave constant result in plant extracts. While plant extracts against gram negative bacteria especially E.coli and E.spp showed activity in acidic $\mathrm{pH}$ only, and these activity was stable in plant extracts application. As well as lactose fermented bacteria K.spp inhibited in different $\mathrm{pH}$, but with low inhibition zone, similar to PS.aeruginosa . 
International Journal of Agriculture, Environment and Bioresearch

Vol. 06, No. 04; 2021

ISSN: $2456-8643$
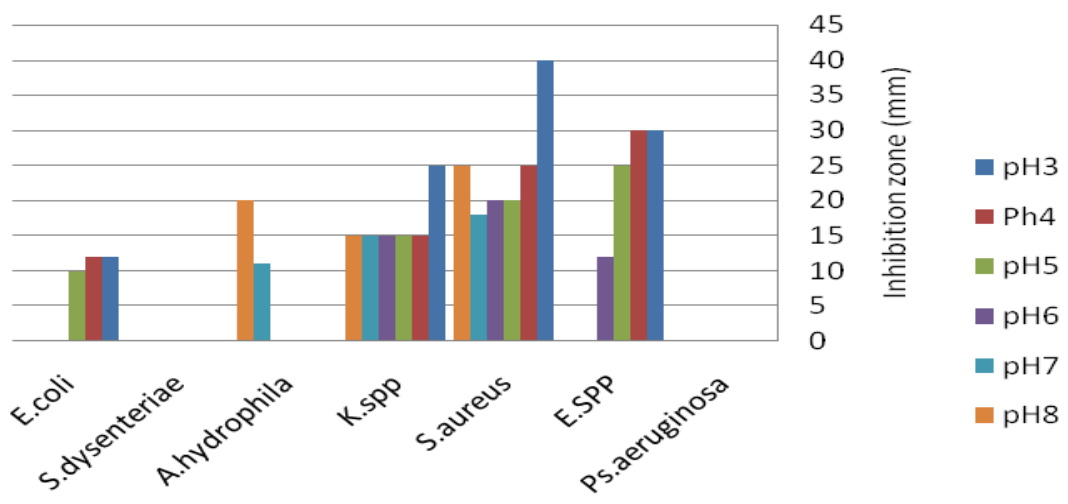

Bacterial strains

Fig 10. Effects of $p H$ on antimicrobial activity of ethanol extract S. rosmarinus

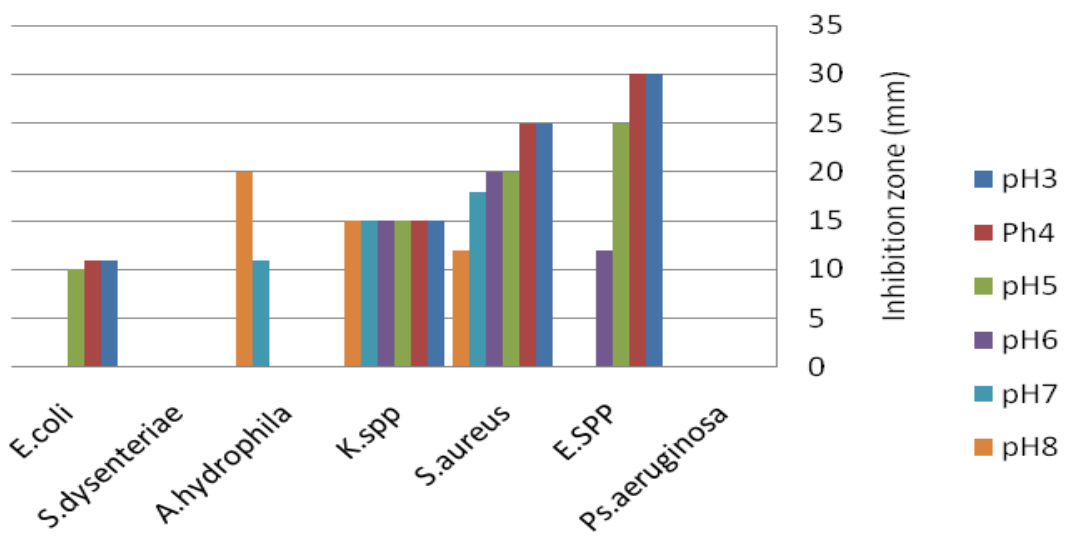

Bacterial strains

Fig 11. Effect of pH on antimicrobial activity of hot aqueous extract S. rosmarinus 


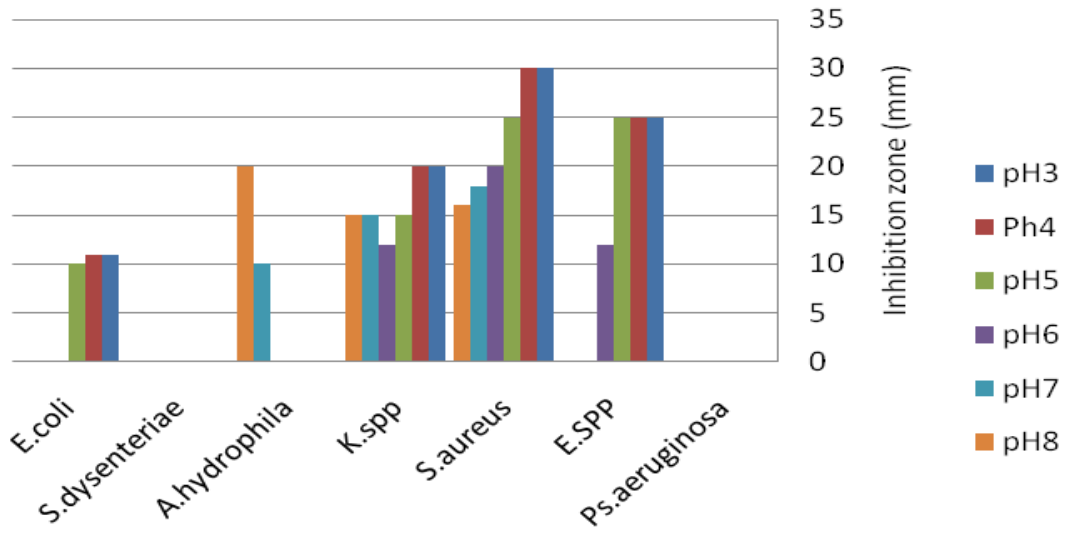

Bacterial strains

Fig 12. Effect of $p H$ on antimicrobial activity of Cold aqueous extract $\mathrm{S}$. rosmarinus

Ten elements, $\mathrm{Ca}, \mathrm{Co}, \mathrm{Cu}, \mathrm{Mn}, \mathrm{Fe}, \mathrm{K}, \mathrm{Na}, \mathrm{P}, \mathrm{Zn}$ and $\mathrm{Pb}$, were determined in $\mathrm{S}$. rosmarinus and Table 7 . S. rosmarinus contained essential elements (Mn, Fe, K, Na,P and Pb,) at higher levels.. Therefore, it may not produce any health risks for human consumption, if other sources of toxic metal contaminated food are not taken at the same time.

Table 7: Essential elements concentration of S. rosmarinus.

\begin{tabular}{|l|l|l|}
\hline Elements & Concentration & S. rosmarinus \\
\hline $\mathrm{Pb}$ & $\mathrm{ppm}$ & 0.6 \\
\hline $\mathrm{Na}$ & $p p m$ & 594 \\
\hline $\mathrm{K}$ & $\%$ & 1.2 \\
\hline $\mathrm{Ca}$ & $\%$ & 0.92 \\
\hline $\mathrm{Fe}$ & $p p m$ & 700 \\
\hline $\mathrm{Zn}$ & $p p m$ & 63.6 \\
\hline$P$ & $\%$ & 0.35 \\
\hline $\mathrm{Mn}$ & $p p m$ & 5.7 \\
\hline $\mathrm{Co}$ & $p p m$ & 2.5 \\
\hline $\mathrm{Cu}$ & $p p m$ & 6.5 \\
\hline
\end{tabular}

\section{CONCLUSION}

Results of this study demonstrated by the aid of S. rosmarinus extracts revealed that this plant has antimicrobial activity against test organisms and this may be suggest the use of this extract in treatment of infectious diseases. 
Vol. 06, No. 04; 2021

ISSN: $2456-8643$

\section{REFERENCES}

1-Khare, C.P. (2004). Encyclopedia of Indian Medicinal Plants, Rational Western Therapy and other Traditional Usage, Botany (Springer Verlag Berlin Meidelberg) . 406-407.

2-Nair, M.G. and Burke, B.A. (1990 ).Antimicrobial metabolite and related compounds. Journal of Agri-cultural and Food Chemistry 38, 1093-1096.

3-Horiuchi, K.; Shiota, S.; Hatano, T. ; Yoshida, T. ; Kuroda, T. and Tsuchiya, T.(2007). Antimicrobial Activity of Oleanolic Acid from Salvia officinalis and Related Compounds on Vancomycin-Resistant Enterococci (VRE). Biol. Pharm. Bull. 30(6) 1147-1149.

4-Eidi,A. ; A. and, Baharc, M.(2006). Effects of Salvia officinalis L. (sage) leaves on memory retention and its interaction with the cholinergic system in rats. Applied and Basic Nutritional Science.22(3): 321-326.

5- Digrak,M.; Alma, M.H.; Ilicim,A.and Sen, S. (1999). Antibacterial and antifungal effects of various commercial plant extracts. Pharm. Biol. 37: 216-220

.6-Lasseigne ,F.T; Stuart, L.W; Frank A .B. and Thomas, G.R.(2007). Day/Night Temperature Affects Growth and Photosynthesis of CultivatedSalvia Taxa. J. Amer. Soc. Hort. Sci. 132(4):492-500.

7-Murphy, R.J (1990). Historical perspective in Europe. Proc. Of First Int.Conf. on Wood Protection with Diffusible Preservatives Ed. Margaret

Hamel, 28-30 Nov. Nashville, Tennessee, pp. 9-13

8-Kartal ,S.N.; Imamura, Y.; Tsuchiya, F.and Ohsata, K. (2004). Preliminary evaluation of fungicidal and termiticidal activities of filtrates from biomass slurry fuel production. Bioresour. Technol. 95(1): 41-47.

9-Schultz, T.P. and Nicholas, D.D. (2000). Naturally durable heartwood: Evidence for purposed dual defensive function of extractives, Phytochemistry 54: 47-52

10-Goktas,O.;Mammadov,R.;EminDuru,M.;Ozen,E. and Colak,A.M.(2007). Application of extracts from the poisonous plant,Salvia rosmarinus L., as a wood preservative.Afric.J.Bio.Tech6(17).2000-2003.

11-Sen ,S.; Hafizoglu, H.and Digrak, M. (2002). Investigation of wood preservative activities of some plant extracts as fungicide, Kahramanmaras Sutcu Imam University, J. Sci. Eng. 5(1): 8698

12- Trease,G.E. and Evans W.C. (2002).Pharmacology.15thg Edn.Saunders Publishers ,London.pp :42-393.

13- Harbome, J. B. (1993) . Phytochemistry .Academic Press, London, pp:89-131.

14-Ogundipe, O.O.; Moody, J.O.; Fakeye, T.O. and Ladip, O.B. (2000). Antimicrobial activity of Mallotus oppositifolium extractives. Afr. J. Med. Med. Sci. Vol. 29: 3/4, pp 281-283.

15-Kudi, A.C.; Umoh, J.U.; Eduvic, L.O.and Getu, J. (1999). Screening of some Nigerian Medicinal plants for Antibacterial Activity. J. Ethanopharm. 67:225-228

16-Reuben,K.D; Abdulrahman,F.I.; Akan,J.C.; Usman, H.; Sodipo, O.A. and Egwu, G.O. (2008). Phytochemical Screening and In Vitro Antimicrobial Investigation of the Methanolic Extract of Croton Zambesicus Muell ARG. Stem Bark. European Journal of Scientific Research,23(1):134140. 
17-Usman, H.; Abdulrahman, F.I. and Ladan ,A.H. (2007). Phytochemical and Antimicrobial Evaluation of Tribulus terrestris L. (Zygophylaceae). Growing in Nigeria. Res. J. Bio. Sci. Medwell Journals, 2007_2(3): 244-247.

18-Franz,C.M.;Toit,D.M.;Holy,H.A.;Schillinger,U. and Holzapfel, W.H.(1997). Production of nisinlike bacteriocins by lactococcus lactis strains isolated from vegetables. J. Basic. Microbiol. 37:187-196.

19-Doughari, J. H., Pukuma, M. S. and De, N.(2007). Antibacterial effects of Balanites aegyptiaca L. Drel and Moringa oleifera Lam. on Salmonella typhi .African Journal of Biotechnology Vol. 6 (19), pp. 221

20-Beyenbach, K.W.(1990). Transport of magnesium across biological membranes.Magnes Trace Elem. 9 :233 -254

21-Nweze, E.T.; Okafor, J.I.and Njoku, O. (2004). Antimicrobial Activities of Methanolic extract of Trumeguineesis (Schumm and Thorn) and Morinda lucinda Benth used in Nigerian Herb. Medicinal Practice. J. Bio. Res. Biotechnol. 2 (1): 34-46.

22-Doughari,J.H. (2006). Antimicrobial Activity of Tamarindus indica Linn .Tropical Journal of Pharmaceutical Research; 5 (2): 597-603.

23-Srinivasan, D.; Perumalsamy, L.P.and Nathan, S. S. T(2001).Antimicrobial activity of certain Indian medicinal plants used in folkloric medicine. J Ethnopharm; 94: 217-222

24-Bushra, N.R. and. Ganga,T. D.( 2003). Antibacterial activity of selected Seaweeds from Kovalam south West coast of India. Asian. J. of Microbiol. Biotech. Env. Sc. 5(3): 319-322 25-Molan, P.C.(1992). The antibacterial activity of honey. The nature of antibacterial activity. Bee World. 73 : 